\title{
National Parks: The determinants of visitors satisfaction in Turkey
}

\author{
Pinar Sivalioglu*, Lale Berkoz \\ Department of Urban and Regional Planning, \\ Istanbul Technical University, Taksim, Istanbul-34469, Turkey \\ *Info@pinarsivalioglu.com
}

\begin{abstract}
Environmental and natural preservation have become a common problem for all the societies of this century. User satisfaction is a concept that lies at the heart of various sectors and work areas today. Place attachment is another concept that has been covered in many research studies conducted until today. Place attachment closely related with satisfaction and includes symbolic and emotional expressions. This paper has been prepared for the purpose of measuring place related satisfaction and attachment of the national park visitors

Keywords: Place attachment; Satisfaction; National park.

eISSN 2514-751X @ C 2018. The Authors. Published for AMER ABRA cE-Bs by e-International Publishing House, Ltd., UK. This is an open-access article under the CC BY-NC-ND license (http://creativecommons.org/licenses/bync-nd/4.0/). Peer-review under responsibility of AMER (Association of Malaysian Environment-Behaviour Researchers), ABRA (Association of Behavioural Researchers on Asians) and CE-Bs (Centre for EnvironmentBehaviour Studies), Faculty of Architecture, Planning \& Surveying, Universiti Teknologi MARA, Malaysia.

DOI: https://doi.org/10.21834/aje-bs.v3i9.301
\end{abstract}




\subsection{Introduction}

Environmental and natural preservation have become a common problem for all the societies of this century. Scientists, today, point out that the rate of environmental deterioration is rapidly growing day by day. Sustainable use and preservation of natural spaces have become a subject these days. The irresponsible exploitation of natural resources for the sole purpose of satisfying human needs has brought about numerous problems in the fragile relations between nature and humankind. Almost all the definitions concerning sustainability and sustainable development require the involvement of posterity in today's decision making process. Also, visitor satisfaction is a key factor for a successful business venture. Satisfaction instigates the possibility of a revisit and determines the experiences the visitors have during the visitation.

\subsection{Literature Review}

\subsection{Place attachment}

Studies on place attachment have enabled us to understand the meanings individuals attach to the physical environment. Interest in human and place relationship is growing day by day. Place attachment and other related terms such as place identity reveal that, these subjects have been investigated and, tested against various scales in almost all research areas in the last 40 years. Place attachment is one of the key concepts covered in this study. The term attachment reflects the sense of place harbored by the individual and includes both the symbolic and affective expressions. The concept of place attachment, in its most general sense, has been used for thousands of years. The term has also been, particularly, employed in studies on natural resource management in the last 15 years (Warzecha and Lime, 2001; Kaltenborn and Williams, 2002; Kyle et al., 2004b; Hwang et al., 2005; Halpenny, 2006).

Morgan (2010) emphasizes that the term place attachment expresses an emotional bond based on a long-term experience with a particular geographical place and the meanings individuals link with that bond. It is possible, on the other hand, for individuals to develop emotional and symbolic bonds with places they have never visited. Emotional and symbolic attachment may also, be defined as identification with a symbolic idea or meaning. The multiplicity of the existing approaches on theoretical and empirical level has, for a while, been the basic problem that the researchers working on attachment have had to cope with it (Hidalgo and Hernandez, 2001). Individual attitude towards places is analyzed by measuring the emotional, cognitive and activity-based reactions and evaluations related with the place (Jorgensen and Stedman, 2001). Studies investigating the relations between human beings and spaces are replete with similar sounding key concepts.

\subsection{User Satisfaction}

User satisfaction lies at the core of various sectors and work areas (housing, commerce, tourism, service industry, recreational satisfaction). Visitors usually have clear expectations as to the quality and types of services that place provides. To what degree their expectations 
met after the visit will determine the visitor satisfaction level.

According to Crosby (1993) and Oderlund (1998), customer satisfaction is increasingly becoming a crucial issue in most service industries (Akama and Kieti, as cited in 2003). With reference to the tourism and hospitality industry, it can be stated that satisfied tourists are more likely to recommend the tourist destination to others, which is the cheapest and most effective form of marketing and promotion. There is usually a positive relationship between tourist satisfaction and the destination's long-term economic success (Akama and Kieti, 2003). Another view defines place satisfaction as a multidimensional and concise judgments about the perceived quality of a place (Stedman, 2002). Satisfaction depends upon many variables. It has been observed, both in recreation and community sociology literature, that social criteria have a significant role (Kyle et al., 2004a).

\subsection{Methodology}

In this study, 5 national parks in the Marmara Region, the most developed region in Turkey in terms of population and economic growth, with different characteristics and highest user density rates have been chosen as the study area. These 5 national parks that are chosen as sample area can be sub-divided into two groups: National parks with natural qualities and national parks with historical qualities. The $1^{\text {st }}$ para should start here...

The questionnaire forms designed to provide relevant data to determine tendencies and evaluate attachment and satisfaction degrees with suitable analysis techniques. The questionnaire conducted face to face in the national parks chosen as the study area during summer months of 2010. As part of the study, the data gathered from the 400 survey forms analyzed and evaluated.

\subsection{Results and Discussion}

The evaluations of survey forms coming from the study area convinced us that it was particularly beneficial to, initially, define visitor profile: It is seen that, of all the national park visitors who joined the research 170 (42.5\%) are female and $230(57.5 \%)$ are male. The sample group is balanced in terms of the gender spectrum, and also $64.1 \%$ of the national park visitors participating in the survey are in 20-40 age range. $270(67.5 \%)$ of the national park visitors participating in the survey are from middle income group. It was also found that the results did not alter when the national parks evaluated separately. The 1 st para should start here...

Table 1. Demographic Characteristics of Survey participants

\begin{tabular}{lll}
\hline & Frequency & Percentage (\%) \\
\hline Gender & & \\
Female & 170 & 42,5 \\
Male & 230 & 57,5 \\
\hline Age & & \\
20 years old and younger & 62 & 15,5 \\
21-30 years old & 185 & 46,3 \\
31-40 years old & 71 & 17,8
\end{tabular}




\begin{tabular}{lll} 
41-50 years old & 51 & 12,8 \\
51 years old and older & 31 & 7,8 \\
\hline Income & \multicolumn{1}{c}{4} \\
High income group & 16 & 4,0 \\
Upper middle income group & 64 & 16,0 \\
Middle income group & 270 & 67,5 \\
Lower middle income group & 35 & 8,8 \\
Low income group & 15 & 3,8 \\
\hline Education & & \\
Primary school & 59 & 15,3 \\
High school & 129 & 33,4 \\
Associate degree & 23 & 6 \\
Undergraduate and graduate & 175 & 45,3 \\
\hline
\end{tabular}

Thus, it can be stated that members of middle income group visit national parks more often than the rest. University graduates and high school graduates constitute the majority of the national park visitors by a $78.7 \%$ ratio (Table 1). The answers to the question that designed to measure overall satisfaction first analyzed totally and then applied factor analysis.

It was found that, of all the national park visitors who joined the research $67.3 \%$ satisfied with their general visiting experiences. $64.4 \%$ of them satisfied with the natural environment quality of the national park. $54.4 \%$ of them satisfied with the quality of the social surroundings of the national park. $43.5 \%$ of them were neither satisfied nor dissatisfied with the possibility of participating in activities, in the national park (Table 2). When the average points are evaluated, natural environment quality of the national park has the highest (3.75) average while participating in favorite activities has the lowest one (3.27). It can, therefore, be said that the overall satisfaction levels of the national park visitors are high.

Table 2. Evaluation of overall satisfaction for national parks

\begin{tabular}{|c|c|c|c|c|c|c|}
\hline $\begin{array}{l}\text { Indicate your satisfaction level with the } \\
\text { following criteria during your last visit to } \\
\text { this park. }\end{array}$ & $\begin{array}{l}\text { Strongly } \\
\text { dissatisfie } \\
\text { d }\end{array}$ & $\begin{array}{l}\text { Dissatisfie } \\
\quad \mathrm{d}\end{array}$ & $\begin{array}{c}\text { Neither } \\
\text { satisfied } \\
\text { nor } \\
\text { dissatisfie } \\
\text { d } \\
\end{array}$ & Satisfied & $\begin{array}{l}\text { Strongly } \\
\text { satisfied }\end{array}$ & Mean \\
\hline Your general experience? & $\begin{array}{l}40 \\
(\% 10.1)\end{array}$ & $\begin{array}{l}36 \\
(\% 9.1)\end{array}$ & $\begin{array}{l}53 \\
(\% 13.4)\end{array}$ & $\begin{array}{l}160 \\
(\% 40.5)\end{array}$ & $\begin{array}{l}106 \\
(\% 26.8)\end{array}$ & 3.65 \\
\hline $\begin{array}{l}\text { Natural environmental quality of the } \\
\text { national park? }\end{array}$ & $\begin{array}{l}12 \\
(\% 3.1)\end{array}$ & $\begin{array}{l}37 \\
(\% 9.4)\end{array}$ & $\begin{array}{l}91 \\
(\% 23.2)\end{array}$ & $\begin{array}{l}151 \\
(\% 38.4)\end{array}$ & $\begin{array}{l}102 \\
(\% 26)\end{array}$ & 3.75 \\
\hline $\begin{array}{l}\text { Social environmental quality of the } \\
\text { national park? }\end{array}$ & $\begin{array}{l}19 \\
(\% 4.8)\end{array}$ & $\begin{array}{l}39 \\
(\% 9.9)\end{array}$ & $\begin{array}{l}121 \\
(\% 30.9)\end{array}$ & $\begin{array}{l}139 \\
(\% 35.5)\end{array}$ & $\begin{array}{l}74 \\
(\% 18.9)\end{array}$ & 3.54 \\
\hline $\begin{array}{l}\text { The possibility of your joining your } \\
\text { favorite activities in the national park? }\end{array}$ & $\begin{array}{l}42 \\
(\% 10.7)\end{array}$ & $\begin{array}{l}24 \\
(\% 6.1)\end{array}$ & $\begin{array}{l}170 \\
(\% 43.5)\end{array}$ & $\begin{array}{l}98 \\
(\% 25.1)\end{array}$ & $\begin{array}{l}57 \\
(\% 14.6)\end{array}$ & 3.27 \\
\hline
\end{tabular}

In order to be able to measure the general attachment points and compare them with the sub-dimensions of place attachment, they were asked to assign a general point. The general sense of attachment of the sample group for the national park has been identified in a scale of $1-10$ points. It was, accordingly, found that 11 of the national park visitors $(2.8 \%)$ partaking in the survey felt no attachment while 93 of them (23.8\%) were extremely much attached 
(Table 3).

Table 3. Evaluation of overall attachment for national parks

\begin{tabular}{|c|c|c|c|c|c|}
\hline Attachment & Frequency & $\begin{array}{l}\text { Percentage } \\
(\%)\end{array}$ & \multirow{9}{*}{\multicolumn{2}{|c|}{$\begin{aligned} 11 & =36 \\
9 & =34 \\
7 & =39 \\
7 & =38 \\
5 & =11 \\
3 & =20 \\
1 & =12\end{aligned}$}} & \multirow[t]{2}{*}{93} \\
\hline 0 & 11 & 2,8 & & & \\
\hline 1 & 20 & 5,1 & & & \\
\hline 2 & 32 & 8,2 & & & \\
\hline 3 & 32 & 8,2 & & & \\
\hline 4 & 27 & 6,9 & & & \\
\hline 5 & 38 & 9,7 & & & \\
\hline 6 & 39 & 10,0 & & & \\
\hline 7 & 28 & 7,2 & & & \\
\hline 8 & 34 & 8,7 & & & \\
\hline 9 & 36 & 9,2 & & 50 & 100 \\
\hline 10 & 93 & 23,8 & & & \\
\hline \begin{tabular}{|l} 
Total \\
\end{tabular} & 390 & 100,0 & & & \\
\hline Mean & & & Stanc & Jard Dvt. & \\
\hline
\end{tabular}

Table 4. Correlation analyses for overall satisfaction and overall attachment

\begin{tabular}{ccccc}
\hline & & $\mathbf{N}$ & $\mathbf{R}$ & $\mathbf{P}$ \\
\hline Overall Attachement & Overall Satisfaction & 385 & 0,254 & 0,000 \\
\hline
\end{tabular}

To find which of the national parks covered in research has the highest attachment ratio, the data were analyzed by means of crosstabs. The analyses showed that Gallipoli and Troy Historical National parks had the highest attachment ratios. This situation can be ascribed to the bonds that individuals have with their history and roots. Gallipoli National Park, where one of the most significant wars in the history of Turkey took place, has the highest attachment degree.

To prove there was any relationship between overall attachment point and overall satisfaction points of the national park visitors joining the survey, a correlation analysis was made. As a result of the correlation analysis, a significant relationship at $25.4 \%$ in the positive direction was found between the points. $(r=0.254 ; p=0.000<0.05)$. As overall attachment level increases the overall satisfaction level increases too (Table 4).

The positive relationship between attachment and satisfaction, which was presumed in this dissertation study, was, thus, verified in the analyses, as well. To prove there was any relationship between overall attachment and overall satisfaction and such factors as demographic characteristics, number of visits to the national park, and the time spent in the national park, a correlation analysis with these variables was carried out. The correlation analysis is significant at levels 0.01 and 0.05 (Table 5). There was, however, a negative relation with educational status at the level of $16.8 \%$. Thus, it seems, the higher educational status is the lower overall satisfaction level becomes. As higher education means higher expectations, when a place fails to meet the expectations, a drop in the satisfaction level is fairly normal.

A positive correlation was found between overall satisfaction and income at the level of 
$17 \%$. The higher the income is the higher the satisfaction level gets. This can be assumed that, as the income level rises the activities in the area become more accessible, opportunities for participating in more activities increase and conditions of access to the area get better.

Table 5. Correlation analyses

\begin{tabular}{lllllll}
\hline & Age & Education & Gender & Income & $\begin{array}{l}\text { Number of } \\
\text { visits to NP }\end{array}$ & $\begin{array}{l}\text { Time spent } \\
\text { in NP }\end{array}$ \\
\hline \multirow{2}{*}{ Overall Satisfaction } &, 005 & $\mathbf{- , 1 6 8 ^ { * * }}$ &, 026 &, $\mathbf{1 7 0 ^ { * * }}$ &, $\mathbf{1 7 9 ^ { * * }}$ &, 023 \\
&, 926 &, 001 &, 611 &, 001 &, 004 &, 652 \\
Overall Attachment & $\mathbf{2 5 1 ^ { * * }}$ & $\mathbf{- , 1 0 4 ^ { * }}$ &, 057 &, 048 &, $325^{* *}$ &, 040 \\
&, 000 &, 044 &, 257 &, 342 &, 000 &, 432 \\
\hline
\end{tabular}

There is also a positive relation between the number of visits to the national parks and overall satisfaction at the level of $17.9 \%$. The higher the satisfaction is the bigger the number of the visits reaches. Significant relation, was not observed between overall attachment and such variables as gender, income, and, time spent in the national park. There is a positive relation between overall attachment and age at a level of $25.1 \%$, which means that as the age rises attachment level rises too. These results are concordant with the findings of similar works in the literature. Between attachment and education level, a negative relation at the level of $10.4 \%$ was found. As educational level rises attachment level decreases. There is a positive relationship between overall attachment and the number of visits to the national park at a level of $32.5 \%$; as attachment increases, there occurs an increase in the number of visits, as well.

Factor analyses and sub-dimensions were structured around the 26 propositions prepared to measure place attachment. The scale used in this study for measuring place attachment is based on the initial efforts of Williams and Roggenbuck (1989) for measuring place attachment. Under the inspiring guidance of the works of Prohansky (1978), Stokols and Shumaker (1981), Jorgensen and Stedman (2001), Halpenny (2006) and Warzecha and Lime (2001), the scale was developed further. For place attachment dimensions, the overall reliability coefficient was calculated to be $\alpha=0.948$, which shows that the scale has high reliability. As a result of $\mathrm{KMO}$ analysis, which was made to test the suitability of this question for the factor analysis, a KMO value of 0.939 was found, which is a remarkably high value and shows that the data set is perfect for the factor analysis. As a result, of the analysis, 4 factors were obtained and these 4 factors explain $64.058 \%$ of the total variance. These four dimensions are called place identity, place dependence, place familiarity and place affect (Table 6).

Table 6. Place attachment sub-factors.

\begin{tabular}{lll}
\hline Sub-factors & Variance & Alpha \\
\hline Place Identity & 44,544 & 0,919 \\
Place Dependence & 8,435 & 0,888 \\
Place Familiarity & 5,666 & 0,848 \\
Place Affect & 5,413 & 0,844 \\
\hline
\end{tabular}


Factor analyses also have been implemented by combining the questions that were prepared to measure satisfaction. As a result of the analyses, it was found that the reliability coefficient (Cronbach alpha) for the satisfaction dimensions of the national park visitors is $\alpha=0.936$. The coefficients for this research are high, which shows that the designed scale has a high level of reliability. As a result of KMO analysis, which was made to test the suitability of this scale for the factor analysis, a KMO value of 0.898 was found, which is a remarkably high value. As a result of the factor analysis, a quadruple factor structure has emerged according to Eigen values. These four factors explain $69.4 \%$ of the total variance. These four factors are called as satisfaction with the physical qualities, satisfaction with the service quality of the historical areas, satisfaction with the equipments, and satisfaction with function areas (Table 7).

Table 7. User satisfaction sub-factors.

\begin{tabular}{lll}
\hline Sub-factors & Variance & Alpha \\
\hline Satisfaction with the physical qualities & 41,057 & 0,841 \\
Satisfaction with the service quality of the historical areas & 13,898 & 0,878 \\
Satisfaction with the equipments & 8,315 & 0,849 \\
Satisfaction with function areas. & 6,158 & 0,851 \\
\hline
\end{tabular}

\subsection{Conclusion}

User satisfaction is a concept that lies at the core of many sectors and work areas today. Understanding user satisfaction provides managers with vital data for developing various services to meet expectations of visitors and make them satisfied with their visiting experiences. Place attachment, on the other hand, is a concept closely related with the concept of satisfaction and comprises emotional and symbolic expressions of individuals. Researches on place attachment contribute to an understanding of the meanings that individuals attach to the physical environment. Interest in the relationship between humans and spaces is growing day by day, and it is only logical since this is the inevitable result of conducting any human-oriented initiative. It has been observed that, in the last years, almost every field has included in their works an analysis of attachment related topics, and analyzed it on different scales.

The aim of this study is to explain concepts of place attachment and satisfaction with their sub-factors and expose the relationship between satisfaction and attachment. Different questions have been used to explain these relationships. As a result of the analyses, it has been found that, in concordance with one of the general hypothesis in this study, there is a positive relationship between overall attachment and overall satisfaction. This positive relation between satisfaction and attachment is, also, consonant with the results of other studies on the same subject (Kyle et al., 2004a, 2004b; Halpenny, 2006).

There is a semantic chaos regarding place attachment and its sub-factors and many researchers have identified different dimensions. Some researchers have identified place identity and place dependence as double dimensions (Stokols and Shumaker, 1981; Kyle et al., 2004a), or, the concept of attachment is examined multidimensional (Kyle et al., 2004b; 
Hammit et al., 2006). The 4 factors obtained in this study; Place Identity (emotional and symbolic identification with a particular place), Place Dependence (functional attachment to a particular place that includes involvement), Place Familiarity (familiarity that grows in time and interaction based on experiences), and Place Affect (emotions and sensations that a particular place arouses in an individual), explain the concept of place attachment.

The satisfaction questions that were devised for that purpose were subjected to a factor analyses and, as a result, 4 sub-factors, which had high reliability values and which reflect overall satisfaction and satisfaction sub-dimensions, were obtained. The highest mean values, in the analyses, were obtained for satisfaction with physical qualities factor and this factor, alone, accounts for the biggest part of the variance.

To sum up, this study investigates the relationship between satisfaction of national park users, the concept of place attachment and satisfaction and place attachment. Identifying the relationship between satisfaction and place attachment concepts will contribute to future work in this area. It has become compulsory to take human-environment relationship and factors that increase satisfaction into consideration in recreational planning. Thus, the needs and expectations of national park users will be met as much as possible, and community participation in planning and administration will be achieved.

\section{References}

Akama, J.S. \& Kieti, D.M. (2003). Measuring tourist satisfaction with Kenya's wildlife safari: a case study of Tsavo West National Park. Tourism Management, 24, 73-81.

Halpenny, E., (2006) Ph.D. Environmental Behaviour, Place attachment and park visitation: A case study of visitors to Point Pelee National Park, University of Waterloo (Canada).

Hammit, W. E., Backlund, E. A. \& Bixler, R. D., (2006). Place bonding for recreation places: Conceptual and empirical development. Leisure Studies, 25, 17-41.

Hidalgo, C.M. \& Hernandez B., (2001). Place Attachment: Conceptual and Empirical Questions. Journal of Environmental Psychology, 21, 273-281.

Hwang, S-N. \& Lee, C., C, H-J., (2005). The relationship among tourists' involvement, place attachment and interpretation satisfaction in Taiwan's national parks. Tourism Management, 26, 143-156.

Kaltenborn, B.P., \& Williams D.R., (2002). The meaning of place: Attachments to Femundsmarka National Park, Norway, among tourists and locals, Nork Geografik Tidsskrift - Norwegian Journal of Geography, 56:3, 189-198.

Kyle, G., Bricker, K., Graefe, A., \& Wickham, T. (2004a). An examination of recreationists' relationships with activities and settings. Leisure Sciences, 26, 123-142.

Kyle, G. T., Mowen, A. J., \& Tarrant, M. A., (2004d). Linking place preferences with place meaning: An examination of the relationship between place motivation and place attachment. Journal of Environmental Psychology, 24, 439454.

Jorgensen, B. S., \& Stedman, R. C., (2001). Sense of place as an attitude: Lakeshore owners attitudes toward their properties. Journal of Environmental Psychology, 21, 233-248. 
Morgan, P., (2010). Towards a developmental theory of place attachment. Journal of Environmental Psychology, $30,11-12$.

Proshansky, H. M., (1978). The city and self-identity. Environment and Behavior, 10(2), 147-169.

Stedman, R. C. (2002). Toward a social psychology of place: Predicting behavior from place-based cognitions, attitude and identity. Environment and Behavior, 34(5), 561-581.

Stokols, D., \& Shumaker, S. A., (1981). People in places: A transactional view of settings. In J. H. Harvey (Ed.), Cognition, social behavior, and the environment. (pp. 441- 488). Hillsdale, NJ: Erlbaum.

Warzecha, C.,A. \& Lime, D., W., (2001). Place Attachment in Canyonlands National Park: Visitors' Assessment of Setting Attributes on the Colorado and Green Rivers, Journal of Park and Recreation Administration, 19, 1, 59-78.

Williams, D.R. \& Roggenbuck, J. W., (1989). Measuring place attachment: Some preliminary results. Paper presented at the session on Outdoor Planning and Management, NRPS Symposium on Leisure Research, San Antonio, Texas. 